Ilmu Pertanian (Agricultural Science)

Vol. 4 No. 2 August, 2019: 59-64

Available online at http://journal.ugm.ac.id/jip

DOI: doi.org/10.22146/ipas.40173

\title{
The Growth and Flowering of Potted Chrysanthemum (Chrysanthemum morifolium Ramat) on Types of Organic Media and Watering Frequent
}

\author{
Ika Rahmawati ${ }^{1,2}$, Endang Sulistyaningsih ${ }^{1 *}$ and Aziz Purwantoro ${ }^{1}$ \\ ${ }^{1}$ Department of Agronomy, Faculty of Agricultur, Universitas Gadjah Mada \\ Jln. Flora no.1, Bulaksumur, Sleman, Yogyakarta 55281, Indonesia \\ ${ }^{2}$ Balai Penelitian Tanaman Hias \\ Jln. Raya Ciherang, Segunung, Pacet, Cianjur 43253, West Java, Indonesia \\ *Corresponding author: endangsih@ugm.ac.id
}

Received: $28^{\text {th }}$ October 2018; Revised: 23 ${ }^{\text {rd }}$ July 2019; Accepted: $29^{\text {th }}$ July 2019

\begin{abstract}
The soils in Samigaluh are mostly dominated by clay and used by farmer for crops production. The growing media for potted chrysanthemum requires additional organic media that could be mixed with the organic material to improve chemical and physical soil properties. Furthermore, the research location is a region with little water in dry season. The research aimed to determine the growth and flower yield response of Avanthe agrihorti to the different organic material mixed with clay and watering frequency. The research was arranged in a split plot design with 3 replications, conducted at an altitude of $462 \mathrm{~m}$ above sea level in the village of Gerbosari, Samigaluh, from March to June 2018. The main plot was watering frequency, i.e. every day, every three days and every five days. The subplot was types of media, i.e. clay + manure, clay + manure + cocopeat, clay + manure + rice husk, and clay + manure + rice husk charcoal. Data on the growth and yield of chrysanthemum plants were observed and statistically analyzed with ANOVA and continued with DMRT test at 5\%. The results showed that the types of media and watering frequency did not significantly give different effect on most of the observed variables. However, Avanthe Agrihorti planted on clay + manure + cocopeat at all watering frequencies showed better growth and yield of flowers than those planted on other media. The efficient watering frequency for Avanthe Agrihorti was every three days. This study provides information for farmers on an alternative method to prepare the best media for the cultivation of potted chrysanthemum on the soil clay.
\end{abstract}

Keywords: Watering frequency, chrysanthemum, organic media.

\section{INTRODUCTION}

The cultivation of potted chrysanthemums in Samigaluh has not intensified even though chrysanthemums cultivation for cut flowers has begun since 2012 (Tarigan, 2018). Chrysanthemum cultivar Avanthe agrihorti is a potential potted chrysanthemum. The characteristics of the cultivar are $27.5-29.0 \mathrm{~cm}$ tall with potential yield of $30-40$ flowers $/ \mathrm{m} 2 /$ season, and developing flowers in 40 50 days after planting. The flowers are purple with $3.89-4.11 \mathrm{~cm}$ diameter and spray - double type.

Samigaluh is located on a medium land at an altitude of 450-500 meter asl with air temperature of $25.15{ }^{\circ} \mathrm{C}$ and humidity of $86 \%$ that supports the growth and development of chrysanthemum. However, in general, its soil condition is unsuitable for chrysanthemum plants. This is because most of the soil in Samigaluh consisted of $72.2 \%$ clay (Latosol). Latosol has low organic matter and poor drainage (Hendrata and Sutardi, 2010). If clay is more dominated at the cultivation area, it must be mixed with organic matter (Crater, 1992).

Clay is not qualified for chrysanthemum cultivation due to its mildly acidic soil reaction and low/very low NPK content. It is compressed in dry condition and is slick during wet conditions. Providing organic materials and manure can be alternative method to improve the physical and chemical properties of the soil which is dominated by clay. Adding organic material will improve the water and pores availability, thus reducing the compactness in dry condition and 
slickness in wet conditions.

According to RKPD Kulon Progo (2019), Gerbosari village is one of three villages lacking of water during dry season. In addition, water resources in Gerbosari are only from wells and mountain springs. The wells are very deep and the farmers need large capacity water pump to collect water from the wells. Water sources from mountain springs are channeled using pipes managed by Drinking Water Enterprise of the village. When dry season is prolonged, in times of water scarcity, water should be shared for various needs of both agricultural irrigation and household consumption. In areas with limited water conditions, it is necessary to obtain efficient watering frequency combined with the addition of organic matter to the media to increase water capacity. Minasny and McBratney (2017) reported an increase in water content with the addition of organic materials, increasing ground water retention directly and indirectly. Watering is important factor in the cultivation of potted plants such as chrysanthemum. Therefore, this study was conducted to obtain the best organic media and the most efficient watering frequency for potted chrysanthemum.

\section{MATERIALS AND METHODS}

The research was carried out in plastic house in Dusun Karang, Gerbosari Village, Samigaluh Sub-district, Kulon Progo from March to May 2018. The material was chrysanthemum cutting of cultivar Avanthe agrihorti.

The research was arranged in Split Plot Design of two factors. The main plot was the watering frecuency, consisting of every day, every three days and every five days. The subplot was the type of media, consisting of soil + manure, soil + manure + cocopeat, soil + manure + rice husk, soil + manure + rice husk charcoal .
The planting media was mixed in a volume ratio $(\mathrm{v} / \mathrm{v})$ based on the treatment and put into a pot $(\varphi 15 \mathrm{~cm})$ at the same weight $(600 \mathrm{~g})$. Before chrysanthemum cuttings were planted, the media was watered until reaching field capacity for eight days, as indicated by the water dripping on the base pot after watering. From the 9th day, watering was applied according to the treatments, i.e. every day, every three days and every five days.

Additional artificial light was given daily every 4 hours between 10:00 p.m - 2:00 a.m from the beginning of the planting to 21 days after planting, arranged by a timer. Basic fertilizer in the form of Gandasil D (2 g. $\left.^{-1}\right)$ was given when at 5 days after planting. Fertilizer of red $\mathrm{KNO}_{3}$ at a dose of $400 \mathrm{ppm}$ was given once a week until flower buds appeared, continued with the application of white $\mathrm{KNO}_{3}$ at a dose of $400 \mathrm{ppm}$, given once a week up to time when the potted flowers were ready for market.

Analysis of physical and chemical properties of the soil was performed on the variables of $\mathrm{pH}, \mathrm{EC}$, porosity, moisture content, bulk density, particle density, organic $\mathrm{C}$ content, and NPK. Media observations during the growth included the humidity and temperature of the media. Plant growth variables observed were dry weight, root volume, leaves temperature, time of transpiration, stomata-opening width, number of leaves, leaf area, plant height, dry weight of plants, days to harvest, number of flower blooms and diameter of flower. All data observed were analyzed using ANOVA with $\alpha 5 \%$ and continued with DMRT test $\alpha 5 \%$ if there were differences between treatments.

\section{RESULTS AND DISCUSSION}

Latosol in Samigaluh consists of $31 \%$ sand, $40.6 \%$ dust, and $28.3 \%$ clay, with $\mathrm{pH}$ value of 5.53 (slightly acidic), low organic C content (0.44), low

Table 1. Initial media analysis of physic and chemis characteristic

\begin{tabular}{|c|c|c|c|c|}
\hline Types of media & clay + manure & $\begin{array}{c}\text { clay }+ \text { manure } \\
+ \text { cocopeat }\end{array}$ & $\begin{array}{l}\text { clay + manure } \\
+ \text { rice husk }\end{array}$ & $\begin{array}{c}\text { clay }+ \text { manure } \\
+ \text { rice husk charcoal }\end{array}$ \\
\hline$\overline{\mathrm{pH}}$ & 5.87 (rather acid) & 5.70 (rather acid) & 5.70 (rather acid) & 5.83 (rather acid) \\
\hline C-organic $(\%)$ & 12.67 (very high) & 12.08 (very high) & 13.94 (very high) & 11.62 (very high) \\
\hline $\mathrm{N}(\%)$ & 0.07 (very low) & 0.25 (medium) & 0.20 (low) & 0.23 (medium) \\
\hline $\mathrm{P}(\%)$ & 0.03 (very low) & 0.04 (very low) & 0.05 (very low) & 0.06 (very low) \\
\hline $\mathrm{K}(\%)$ & 0.07 (very low) & 0.25 (very low) & 0.23 (very low) & 0.23 (very low) \\
\hline Particle density & $2.13\left(\mathrm{~g} \cdot \mathrm{cm}^{-1}\right)$ & $2.12\left(\mathrm{~g} \cdot \mathrm{cm}^{-1}\right)$ & $2.12\left(\right.$ g.cm $\left.\mathrm{cm}^{-1}\right)$ & $2.09\left(\mathrm{~g} . \mathrm{cm}^{-1}\right)$ \\
\hline
\end{tabular}

Remark: Parameter values according to Balai Penelitian Tanah (2005). 


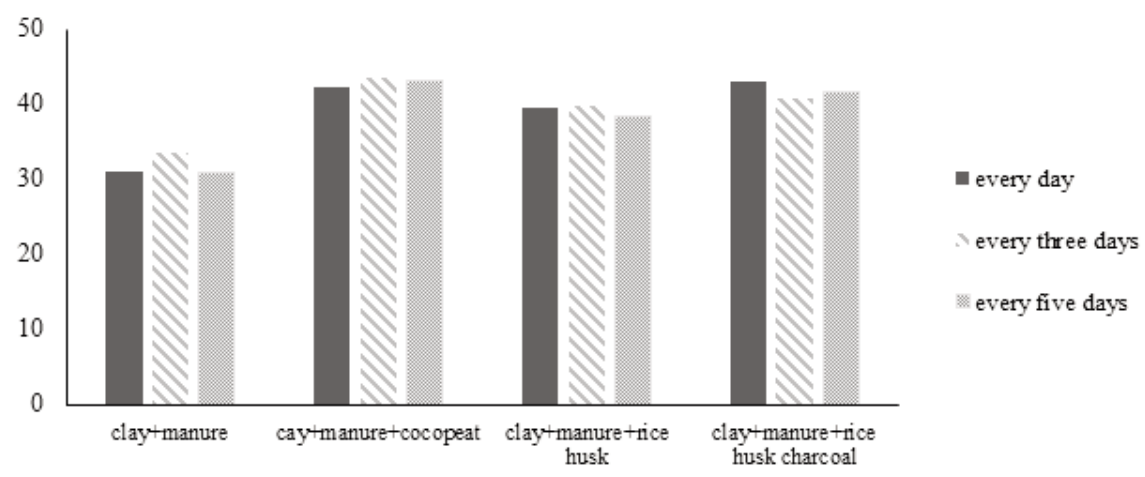

Figure 1. Volume of watering in the first 15 days of treatment (ml)

Table 2. Media temperatures and moistures for 81-83 dap (days after planting)

\begin{tabular}{lc}
\hline Treatment & Media Temperature $\left({ }^{\circ} \mathrm{C}\right)$ \\
\hline Watering frequent & $32.65 \mathrm{p}$ \\
\hline Every day & $32.97 \mathrm{p}$ \\
Every three days & $33.35 \mathrm{p}$ \\
Every five days & $33.03 \mathrm{a}$ \\
\hline Types of Media & $32.68 \mathrm{a}$ \\
\hline clay + manure & $33.02 \mathrm{a}$ \\
clayl+manure + cocopeat & $33.22 \mathrm{a}$ \\
clay+manure + rice husk & $(-)$ \\
clay+manure+ rice husk charcoal & 3.78 \\
\hline Interaction & \\
\hline CV $(\%)$ & \\
\hline Remark: Means followed by the same letters in the same column and \\
treatment factor are not significantly different based on the \\
DMRT at 5\%. (-) shows no interaction between treatments.
\end{tabular}

$\mathrm{N}(0.1 \%)$, very low $\mathrm{P}(0.03 \%)$, very low $\mathrm{K}(0.07 \%)$ and particle density of $2.37 \mathrm{~g} . \mathrm{cm}^{-3}$. The soil is classified into the clay loam texture (USDA, 2019) .

Adding organic material (cocopeat/rice husk/rice husk charcoal) to the media with latosol would cause changes on the soil physical and chemical properties. The media experienced a increase in the $\mathrm{pH}$ value (from 5.53 to 5.70-5.83) and a decrease in particles density from 2.37 to be $2.09-2.13 \mathrm{~g} . \mathrm{cm}^{-1}$ (Table 1). The decreasing particle density of soil indicates a decrease in soil density. The decrease in particle density of media is related to the increment of media pores. Media with high pores would have enough oxygen for root growth. However, the media with organic matter showed low - medium $\mathrm{N}$ content and low $\mathrm{P}$ and $\mathrm{K}$ content.

According to Suntoro (2003), the addition of organic material to the soil caused the heavy clay soil with coarse and strong lumpy structures to become finer, not coarse, with the improvements of the soil $\mathrm{pH}$, cation and anions exchange capacity, structure, soil aggregation and aeration as well as the capacity to hold water.

Volume of watering during the first 15 days of the treatment could be seen in Figure 1. The media of clay + manure had the lowest volume and media of clay + manure + cocopeat and clay + manure + rice husk charcoal had the highest volume in all watering frequencies.

The addition of organic material especially clay + manure + cocopeat could increase water holding in the media, leading to high moisture availability in the media compared to media added with manure. This moisture can be absorbed by root for plant growth. According to Siahaya (2007), water in xylem flow the nutrient from roots to all part of the plant and directly influence photosynthesis.

Media of clay + manure + cocopeat needed high volume of watering which had high water availability (Figure1) although the temperature of the media 
Table 3. Dry weight and volume of root

\begin{tabular}{lcc}
\hline Treatment & Dry weight of root $(\mathrm{g})$ & Volume of root $\left(\mathrm{cm}^{3}\right)$ \\
\hline Watering frequent & & \\
\hline Every day & $1.08 \mathrm{q}$ & $3.72 \mathrm{q}$ \\
Every three days & $0.97 \mathrm{q}$ & $5.66 \mathrm{p}$ \\
Every five days & $1.29 \mathrm{p}$ & $4.55 \mathrm{pq}$ \\
\hline Types of Media & & \\
\hline clay + manure & $0.85 \mathrm{~b}$ & $2.01 \mathrm{~b}$ \\
clayl+manure +cocopeat & $1.11 \mathrm{a}$ & $6.18 \mathrm{a}$ \\
clay+manure +rice husk & $1.21 \mathrm{a}$ & $5.13 \mathrm{ab}$ \\
clay+manure+ rice husk charcoal & $1.28 \mathrm{a}$ & $5.26 \mathrm{ab}$ \\
\hline Interaction & $(-)$ & $17.85^{*}$ \\
\hline CV $(\%)$ & $17.71^{*}$ & \\
\hline Remark: Means followed by the same letters in the same column and treatment factor are not significantly \\
$\quad$ different based on the DMRT at $5 \% .(-)$ shows no interaction between treatments.
\end{tabular}

Table 4. Leaves temperatures, time of transpiration, stomata-opening widht

\begin{tabular}{|c|c|c|c|}
\hline Treatment & $\begin{array}{c}\text { Leaves } \\
\text { temperature }\left({ }^{\circ} \mathrm{C}\right)\end{array}$ & $\begin{array}{c}\text { Time of transpiration } \\
\left(\text { second. } \mathrm{cm}^{-2}\right)\end{array}$ & $\begin{array}{c}\text { Stomata-opening } \\
\text { widht }(\mu \mathrm{m})\end{array}$ \\
\hline \multicolumn{4}{|l|}{ Watering frequent } \\
\hline Every day & $29.87 \mathrm{q}$ & $59.28 \mathrm{q}$ & $3.05 \mathrm{p}$ \\
\hline Every three days & $30.18 \mathrm{q}$ & $69.58 \mathrm{q}$ & $3.02 \mathrm{p}$ \\
\hline Every five days & $31.38 \mathrm{p}$ & $163.30 \mathrm{p}$ & $3.21 \mathrm{p}$ \\
\hline \multicolumn{4}{|l|}{ Types of Media } \\
\hline clay + manure & $30.94 \mathrm{a}$ & $91.12 \mathrm{ab}$ & $2.64 \mathrm{c}$ \\
\hline clayl + manure + cocopeat & $29.55 \mathrm{~b}$ & $71.87 \mathrm{~b}$ & $3.44 \mathrm{a}$ \\
\hline clay + manure + rice husk & $30.66 \mathrm{a}$ & $126.60 \mathrm{a}$ & $3.10 \mathrm{~b}$ \\
\hline clay + manure + rice husk charcoal & $30.75 \mathrm{a}$ & $99.97 \mathrm{ab}$ & $3.12 \mathrm{ab}$ \\
\hline Interaction & $(-)$ & $(-)$ & $(-)$ \\
\hline$\overline{\mathrm{CV}(\%)}$ & 2.42 & $26.63 *$ & 9.73 \\
\hline
\end{tabular}

was not different from that of other media (Table 2). High water availability in this media accelerated the time of transpiration $\left(71.87\right.$ second. $\left.\mathrm{cm}^{-2}\right)$. This indicated rapid water vapor movement that passed through the stomata into the air. Thus, carrying moisture from the media and releasing it on the surface of the leaves to make the stomata opening wider $\left(3.44 \mu \mathrm{m}^{2}\right)$. Due to the continuous and abundant supply of water from the roots to the leaves, the leaves cooled faster than the surrounding air (Table 4). This condition supported the plant growth, resulting in high dry weight and root volume (Table 3 ).

According to Anetasia et al. (2013), media with a lot of water availability usually has low temperature, making it easier for the root to absorb more water. That condition causes the roots in media with organic matter to be more dense, resulting in higher dry weight and volume of root compared to the roots in media without the addition of organic matter. As a result, plant can absorb nutrition optimally. Vas Monteiro et al. (2016) reported that increasing water absorption could increase transpiration, lowering the leaves temperature quickly. High transpiration rates also lead to faster water loss, which can reduce the leaf temperature.

Leaf temperature was influenced by both treatment factors, however, there was no interaction effect between treatments. Plants with frequent watering showed lower leaf temperatures than those with infrequent watering. The number of leaves was influenced by the watering frequency and media combination, although there was no interaction effect between the two factors. Plants watered every five days produced the lowest number of leaves than 
Table 5. Leaf area at harvest $\left(\mathrm{cm}^{2}\right)$

\begin{tabular}{|c|c|c|c|c|c|}
\hline \multirow[b]{2}{*}{ Treatments } & \multicolumn{4}{|c|}{ Types of media } & \multirow[b]{2}{*}{ Average } \\
\hline & clay + manure & $\begin{array}{l}\text { clay }+ \text { manure } \\
+ \text { cocopeat }\end{array}$ & $\begin{array}{l}\text { clay+manure } \\
\text { +rice husk }\end{array}$ & $\begin{array}{l}\text { clay }+ \text { manure }+ \\
\text { rice husk charcoal }\end{array}$ & \\
\hline Every day & $408.63 \mathrm{bc}$ & $416.31 \mathrm{bc}$ & $416.13 \mathrm{bc}$ & $399.53 \mathrm{bc}$ & 410.15 \\
\hline Every three days & $388.47 \mathrm{bc}$ & $589.36 \mathrm{a}$ & $361.10 \mathrm{bc}$ & $363.90 \mathrm{bc}$ & 425.71 \\
\hline Every five days & $291.95 \mathrm{c}$ & $434.15 \mathrm{~b}$ & $324.17 \mathrm{bc}$ & $360.44 \mathrm{bc}$ & 352.68 \\
\hline Average & 363.02 & 479.94 & 367.13 & 374.62 & $(+)$ \\
\hline
\end{tabular}

Remark: Means followed by the same leters in the same column and row are not significantly different. $(+)$ means there is an interaction between the two treatments.

Table 6. Plant height, number of leaves and dry weight plant

\begin{tabular}{lccc}
\hline Treatment & Height $(\mathrm{cm})$ & Number of leaves & Dry weight plant $(\mathrm{g})$ \\
\hline Watering frequent & & & \\
\hline Every day & $23.00 \mathrm{p}$ & $121.41 \mathrm{p}$ & $5.49 \mathrm{p}$ \\
Every three days & $22.58 \mathrm{p}$ & $121.25 \mathrm{p}$ & $5.45 \mathrm{p}$ \\
Every five days & $21.55 \mathrm{p}$ & $98.66 \mathrm{q}$ & $4.58 \mathrm{q}$ \\
\hline Types of Media & & & \\
\hline clay + manure & $20.22 \mathrm{~b}$ & $105.11 \mathrm{~b}$ & $4.16 \mathrm{c}$ \\
clayl+manure +cocopeat & $23.3 \mathrm{3a}$ & $127.22 \mathrm{a}$ & $6.15 \mathrm{a}$ \\
clay+manure +rice husk & $22.44 \mathrm{a}$ & $114.11 \mathrm{ab}$ & $5.12 \mathrm{bc}$ \\
clay+manure+ rice husk charcoal & $23.55 \mathrm{a}$ & $108.66 \mathrm{~b}$ & $5.28 \mathrm{ab}$ \\
\hline Interaction & $(-)$ & $(-)$ & $(-)$ \\
\hline CV $(\%)$ & 8.17 & 9.45 & 16.72 \\
\hline
\end{tabular}

Remark: Means followed by the same letters in the same column and treatment factor are not significantly different based on the DMRT at 5\%. (-) shows no interaction between treatments.

Table 7. Days of harvest (dap), numbers of flower and flower diameter at harvest

\begin{tabular}{lccc}
\hline Treatment & $\begin{array}{c}\text { Days of harvest } \\
\text { (dap) }\end{array}$ & $\begin{array}{c}\text { Numbers of flower } \\
\text { bloom per pot }\end{array}$ & $\begin{array}{c}\text { Flower diameter } \\
\text { (cm) }\end{array}$ \\
\hline Watering frequent & \multicolumn{3}{c}{} \\
\hline Every day & $81.50 \mathrm{p}$ & $13.25 \mathrm{p}$ & $3.34 \mathrm{p}$ \\
Every three days & $81.25 \mathrm{p}$ & $11.16 \mathrm{p}$ & $3.29 \mathrm{p}$ \\
Every five days & $82.75 \mathrm{p}$ & $12.16 \mathrm{p}$ & $3.28 \mathrm{p}$ \\
\hline Types of Media & & & \\
\hline clay + manure & $83.77 \mathrm{a}$ & $9.88 \mathrm{~b}$ & $2.64 \mathrm{~b}$ \\
clayl+manure +cocopeat & $80.88 \mathrm{~b}$ & $14.11 \mathrm{a}$ & $3.63 \mathrm{a}$ \\
clay+manure +rice husk & $81.33 \mathrm{~b}$ & $12.50 \mathrm{a}$ & $3.51 \mathrm{a}$ \\
clay+manure+ rice husk charcoal & $81.33 \mathrm{~b}$ & $12.20 \mathrm{a}$ & $3.43 \mathrm{a}$ \\
\hline Interaction & $(-)$ & $(-)$ & $(-)$ \\
\hline CV $(\%)$ & 2.62 & 23.89 & 12.16 \\
\hline
\end{tabular}

Remark: Means followed by the same letters in the same column and treatment factor are not significantly different based on the DMRT at 5\%. (-) shows no interaction between treatments.

plants treated with other watering intervals. The highest number of leaves was observed in the plants grown on clay + manure + cocopeat even though the number of leaves was not different from those grown on the clay + manure + rice husk (Table 6 ). High number of leaves of potted chrysanthemum planted on clay + manure + cocopeat promoted wide leaf area (Table 5). Wide leaf area contributed to high photosynthesis, and would accumulate high plant dry weight (Table 6) 
The growth rate of chrysanthemum plants on media added with organic material was higher than those planted on media without organic matter. Media with organic material produced plant heights of $22.44-23.55 \mathrm{~cm}$, while the addition of single manure on clay produced plant heights of $20.22 \mathrm{~cm}$ (Table 7).

Plants given the additional organic material could be harvested earlier with larger number and diameter of flowers than those without additional organic material. Types of organic media applied did not show significant difference on the days to harvest. However, plants on media of clay + manure + cocopeat showed earlier harvest time i.e. 2 days than those on media of clay + manure (Table 7). The largest number of blooming flowers was observed in media of clay + manure + cocopeat (14.11 buds per pot). According to Padhiyar et al. (2017), the increasing number of flowers per plant was due to the influence of the overall vegetative growth of plants grown on the media, including carbohydrate accumulation from photosynthesis, which supported by the balance and availability of nutrients in such media. Media added with organic matter produced larger flower diameters $(3.43-3.63 \mathrm{~cm})$ than without organic matter $(2.64$ $\mathrm{cm})$ (Table 7).

\section{CONCLUSIONS}

Chrysanthemum cultivar Avanthe Agrihorti planted on media of clay + manure + cocopeat at all watering frequencies showed the best growth and yield of flowers. The efficient watering frequency for Chrysanthemum cultivar Avanthe Agrihorti was watering every three days.

\section{REFERENCES}

Anetasia, M., Afandi, H. Novpriansyah, K.E.S. Manik dan P. Cahyono. 2013. Perubahan kadar air dan suhu tanah akibat pemberian mulsa organik pada pertanaman nanas P.T. Great Giant Pineapple Terbanggi Besar Lampung Tengah. J. Agrotek Tropika., 1: 213-218.

Balai Penelitian Tanah. 2005. Petunjuk Teknis: Analisis Kimia Tanah, Tanaman, Air dan Pupuk. Badan Penelitian dan Pengembangan Pertanian. Departemen Pertanian. 143p.
Crater, G.D. 1992. Potted chrysanthemums. p. 249-287: In Larson 2nd (ed). Introduction Floriculture. Department of Horticultural Science. North Carolina State University. Raleigh. North Carolina.

Hendrata, R dan Sutardi. 2010. Evaluasi media dan frekuensi penyiraman terhadap pertumbuhan bibit Kakao (Theobroma cacao .L). Agrovigor., 3: 10-18.

Minasny, B. and A.B. McBratney. 2017. Limited effect of organic matter on soil available water capacity. European J. of Soil Science., 69: 39-47.

Padhiyar, BM., D.S. Bhatt, K.D. Desai, V.H. Patel and J.R.Chavda. 2010. Influence of different potting media on growth and flowering of pot chrysanthemum var. Ajina purple. Inter. J. of Chemical Studies., 5: 1667-1669.

RKPD (Rencana Kerja Pemerintah Daerah Kulon Progo) TA. 2018. Peta rawan kekeringan Kabupaten Kulonprogo. https://www. bappeda. kulonprogo kab. go.id/> 701p.

Siahaya, L., 2007. Pengaruh media tumbuh dan frekwensi penyiraman terhadap pertumbuhan awal semai Salimuli (Cordiasubcordata, Lamk). J. Agroforestri, 2:19-26.

Saprianto dan N.H. Panjaitan. 1999. Efisiensi penggunaan air pada sistem irigasi tetes dan curah untuk tanaman krisan (Chrysantemum sp). Buletin Keteknikan Pertanian., 13: 11-20.

Suntoro, A. W. 2003. Peranan bahan organik terhadap kesuburan tanah dan upaya pengelolaannya. Pidato Pengukuhan Guru Besar Ilmu Kesuburan Tanah. Fakultas Pertanian Universitas Sebelas Maret. 36 p.

Tarigan, K. 2018. Bimbingan teknis dan pengawalan kawasan florikultura. http://hortikultura. pertanian. go.id/? $p=2411$.

USDA, 2019. Soil texture calculator. https:// www. nrcs.usda.gov/wps/portal/nrcs/detail/soils/sur vey.

Vas Monteiro, M., T. Blanusa, A. Verhoef, P. Hadley and R.W.F. Cameron. 2016. Relative importance of transpiration rate and leaf morphological traits for the regulation temperatur. Australian Journal of Botany. 64: 32-44. 